UDK 781.6(497.4)

Gregor Pompe

Filozofska fakulteta Univerze v Ljubljani

Faculty of Arts, University of Ljubljana

\title{
Sodobna slovenska kompozicijska praksa in muzikologija
}

\section{Contemporary Slovene Compositional Practice and Musicology}

\begin{abstract}
Ključne besede: metodologija muzikologije, sodobne kompozicijske tehnike, glasbeno mišljenje, postmodernize
\end{abstract}

POVZETEK

V članku avtor shematično pregleda stanje v sodobni metodologiji muzikološke stroke in sočasni kompozicijski praksi s posebnim ozirom na slovensko ustvarjalnost. Pri tem se razkrivajo številne duhovnozgodovinske vzporednice: tako sodobno muzikologijo kot kompozicijo je zaznamovalo postmodernistično razsrediščenje, sobivanje povsem disparatnega in pluralizem. V ospredju ni samo ena metodološka paradigma, zato se poudarek iz metode prenaša na preiskovani predmet, hkrati pa je podrta epistemološka hierarhija. Temu ustrezno je kompozicijo zaznamoval dokončni razpad skladateljskega metiera - skladatelj danes ne more več obvladovati celotnega kompozicijskega arzenala, zaradi česar je še bolj pomembna vez med mislijo o glasbi (muzikologija) in glasbenim mišljenjem (kompozicija).

V nadaljevanju avtor analizira skladateljske zapise $\mathrm{v}$ koncertnih listih in $\mathrm{v}$ njih išče verbalne ostanke glasbenega mišljenja. Pregled takih zapisov razkriva različno stopnjo reflektiranosti skladateljskih misli, ki segajo od prigodniških, tavtoloških zapisov, navajanja okoliščin, ki so pripeljale do ideje za skladbo, poetičnega programa, do analitičnih prerezov skladb in predstavljanja kompozicijske ali strukturalne problematike. Skladatelji, zavezani
Keywords: methodology of musicology, contemporary compositional techniques, musical thinking, postmodernism

SUMMARY

In this article, the author gives a schematic survey of current methodology in musicology and of synchronous compositional practice with special regard to Slovene creativity. In the process, numerous philosophical parallels come to the fore: both contemporary musicology and composition have been marked by postmodernistic defocusing, coexistence of disparaties, and pluralism. In the foreground, there is not only one methodological paradigm, so that emphasis is being transferred from methodology to the subject under consideration, while the epistemological hierarchy has been shattered. Correspondingly, in composition, the composer's métier has fallen apart, since today no one can master the entire compositional arsenal, so that ties between thinking on music (musicology) and musical thinking (composition) have become ever more important.

Subsequently, the author analyses composers' utterances in concert notes, seeking verbal remnants of their musical thinking. A survey of such records reveals various levels of reflection, ranging from accidental, tautological utterances, explaining the circumstances that brought about the initial idea for a new composition, or its poetic programme, to analytical cross sections of individual works, as well as pre- 
modernističnim iskanjem, namenjajo več pozornosti misli o glasbi in živijo v ozki zvezi z muzikološkim razgrajevanjem sodobne ustvarjalnosti, manj pa so reflektirana snovanja skladateljev, ki postavljajo svoje delo v zvezo s postmodernizmom. Kvantitativno prevladuje slednja skupina skladateljev, zato je odkrita slaba povezanost med slovensko kompozicijsko prakso in muzikologijo. sentations of compositional and structural problems. Thus, composers, that follow modernistic trends, pay more attention to thought on music, and live in close touch with musicological deconstruction of contemporary creativeness, whereas the endeavours of those composers who relate their work to postmodernism appear to be less reflected. Quantitatively, the latter group of composers is prevalent, hence the loose connectedness between Slovene compositional practice and musicology.

Naslov članka vključuje kar tri problemska območja: sodobno slovensko kompozicijsko prakso, problematiko sodobne muzikologije in njene metodologije ter povezavo med obema širokima področjema; zanimalo me bo torej, v kakšnem medsebojnem odnosu sta sodobna slovenska glasbena ustvarjalnost in sodobna muzikologija kot znanost o tej ustvarjalnosti - ali vplivata druga na drugo, obstajajo med njima trenja, ali poteka morda njun razvojni tok indiferentno eden mimo drugega. Glede na to, da sta obe glavni problemski sidrišči - kompozicijsko in muzikološko - precej obsežni, bo v mojem prispevku ključen poudarek namenjen prav vprašanju njunega medsebojnega prežemanja oz. neodvisnosti.

Podobno kot za kompozicijska snovanja zadnjih dveh desetletij v Evropi je tudi za slovensko sodobno glasbo značilno postmodernistično slogovno razsrediščenje, katerega ena izmed glavnih značilnosti je sobivanje povsem disparatnega. Pri tem se je treba nujno zavedati, da slovenski glasbeni prostor sodi na geografsko obrobje glasbene Evrope, kar pomeni, da vanj ves čas dotekajo novi tokovi - včasih dokaj promptno, drugič tudi $z$ relativno zamudo -, vendar pa se glavni signali od centra do obrobja pogosto popačijo, zato je za "slovensko resno muziko obdobja, ki se ga je oprijela oznaka postmoderna " ${ }^{1}$ potrebno vzpostaviti posebne kriterije: v njej namreč močneje bivajo lokalni odmevi in osebna predrugačenja kakor izvorna ideja postmodernizma. Posledica lokalnih specifik sodobnega slovenskega kompozcijskega ustvarjanja se še najbolj kaže v relativni nekonfliktnosti različnih, v času brez vsakršnih orientirjev seveda popolnoma legitimnih avtorskih poetik. Zato je tudi mogoče, da Leon Stefanija ${ }^{2}$ pri pregledovanju kompozicijskih zasnov v slovenski instrumentalni glasbi zadnjih petindvajsetih let uporablja relativno enotno metodološko orodje, ki mu omogoča, da v luči prežemanja "starega" in "novega" oz. "predrugačenja minulega" kot osrednjo značilnost izpostavlja prav različne oblike "dialoga s preteklostjou: poleg historičnega in historicističnega še transhistoricističnega, katerega glavne "Značilnosti so zvočni vzorci, ki se izmikajo vzporednicam z minulimi ali obstoječimi kompozicijskimi predlogami, čeprav bi jih mogli izslediti v 'estetskem kapitalu' (N. Cook) Nove glasbe." ${ }^{3}$ Prav zadnji "tip estetike", značilen za slovensko glasbeno

1 Leon Stefanija, Kompozicijske zasnove $v$ slovenski instrumentalni glasbi zadnje četrtine 20. stoletja, v: Muzikološki zbornik 37 (2001), str. 114.

2 Prim.: prav tam in isti, Umevanje «starega" in "novega" $v$ novejši slovenski glasbi, diss., Ljubljana 1999.

3 Isti, Kompozicijske zasnove $v$ slovenski instrumentalni glasbi zadnje četrtine 20. stoletja, str. 119. 
sodobnost pa prinaša pomembno spoznanje: tudi za izmikanje "staremu", zvestobi idejama stalne inovacije in napredka je potreben odnos do "starega", torej poznavanje tradicije in $\mathrm{z}$ njo zgodovine. Za sodobno slovensko kompozicijsko prakso so značilne nasprotnosti, "Sočasnost različnega", pluralistične estetike, vendar pa le-te nikoli ne zapadajo ekstremơm. Tako skladatelji, ki želijo v kvazipostmodernistični maniri poudarjeno razpirati komunikacijo s čim večjim številom konvencionalno izobraženih poslušalcev, iščejo rešitve v apliciranju in sopostavljanju modelov iz glasbene preteklosti, manj pa nanje vplivajo vzorci iz popularne glasbe ali celo filozofskoreligiozne tendence neevropskih kultur, na drugi strani pa se skladatelji, ki vsaj v svojih estetskih proklamacijah ostajajo zavezani modernistični doktrini, ne navezujejo na najbolj radikalne variante Nove glasbe - avantgardistična razbijanja tradicionalno pojmovanega umetniškega dela in umetniške prakse ali totalno organizirana serialna dela -, temveč sledijo bolj "Zmerni" "poljski šoli" (predvsem dvojcu K. Penderecki - W. Lutosławski), v kateri so najbolj odločna modernistična snovanja "Samo" odmevala.

Tako kot sodobne kompozicijske prakse pa je razsrediščenje zaznamovalo tudi sodobno muzikologijo. V ospredju ni samo ena metodološka šola oz. raziskovalna paradigma, $s$ katere orodjem bi raziskovali vsi muzikologi, zato so vse manj mogoče sprotne primerjave in aksiološke sodbe. Tak "metodološki pluralizem" ${ }^{4}$ ima seveda tako svoje svetle kot tudi nekoliko temnejše plati. Končno je tako mogoče, da izbrani, preiskovani predmet narekuje izbiro metode, $s$ čimer se poudarek iz značilne perspektive izbrane metode prenaša na predmet sam, obenem pa omogoča istočasna izbira najrazličnejših metod tudi osvetlitev istega predmeta iz različnih, včasih tudi diametralno nasprotnih smeri, kar prispeva k plodnemu dopolnjevanju znanja "ideološke" metodološke vojne in različna dokazovanja o smotrnosti izbranih metod so tako večinoma končane. Bolj problematična pa v takem skupinskem metodološkem "loncu" postaja epistemološka hierarhija. Že tako kompleksna sistematizacija metod, ki je vedno vpeta v širši kontekst ${ }^{5}$ - tega določajo subjekt, ki metodo uporablja (tudi: perspektiva), predmetno področje, ki mu je ta uporaba prirejena in cilj, h kateremu je naravnana -, se zaradi "dvosmernosti" metod, ki niso vezane na specifično predmetno področje, še bolj zapleta. Samo za primer: ali se rezultati antropologa, ki raziskuje glasbo, in muzikologa, ki pri svojem preučevanju uporablja antropološko metodo, kaj razlikujejo? Metode, kakršna je tudi antropologija, silijo vede $z$ natančno določenim, največkrat ožjim in omejenim predmetnim področjem, $\mathrm{k}$ odpiranju teh meja in neslutenemu širjenju svojega predmeta. Zato je danes praktično nemogoče, da bi imeli pregled nad celotnim znanjem in metodološkim spektrom neke vede, kot posledica take razpršenosti in "razlitja" pa se kaže močno omejena možnost vrednotenja: posameznih raziskav in $\mathrm{v}$ primeru naše vede tudi umetniških predmetov.

Iz takega kratkega, shematičnega in zato seveda tudi nepopolnega pregleda sodobne kompozicijske in muzikološke prakse je razvidno, da obe področji človekovega duha vendarle zaznamujejo skupne težnje - tako kompozicija kot tudi muzikologija sta močno zaznamovani $z$ duhom časa. Za naše osrednje vprašanje pa je še

${ }_{5}^{4}$ Prim.: Janko Kos, Uvod v metodologijo literarne vede, v: Primerjalna knjižeunost 11 (1988), št. 1, str. 1-18.

5 Prim.: prav tam. 
pomembneje, ali med kompozicijo in muzikologijo poleg duhovnozgodovinske obstaja še kakšna druga vez. Gre pravzaprav za večno dilemo o razmerju med glasbenim mišljenjem, ki "Označuje središče ustvarjanja glasbe, pravo prizorišče nastajanja umetnin, - samo pa ostaja nevidno " ${ }^{6}$ in mislijo o glasbi kot osrednjo muzikološko domeno.

Marija Bergamo je smiselno, s pomočjo kratkega zgodovinskega prereza pokazala, da "[t]ako kot je glasba ena nepogrešljivih konstituant človekove biti v vsej zgodovini njenega obstoja, je misel o glasbi, ki jo ne le spremlja, temveč pogojuje in opredeljuje - del življenja glasbe skozi stoletja." ${ }^{7} \mathrm{Kljub}$ temu, da se je skozi zgodovino vse bolj trgala enovita popkovina, ki je v svojih začetkih vezala enovitost glasbe in misli o glasbi, pa Bergamova na ozadju Eggebrechtove teze o tem, da glasbo sestavljata "mathesis" in emocija, pri čemer tudi slednje ni mogoče doseči drugače kot s pomočjo racionalnosti, svoj ekspoze zaključuje $\mathrm{z}$ mislijo, da se skladatelj in muzikolog "ne $\mathrm{v}$ - metodi, ne v obvladovanju veščin, ki so potrebne za glasbeno upodabljanje oz. muzikološko interpretacijo, ne razhajata." ${ }^{8}$ Tak zaključek je seveda mogoče razumeti tudi kot apologijo muzikologovih znanj; muzikolog, raziskovalec skladatelju ni inferiorni oproda, temveč samosvoj "umetnik", ki se do bistva, iz katerega se je rodila skladateljeva glasba, skuša dokopati v obratni smeri: če skladatelj "potuje « od zamisli, osrednje "glasbene misli" k izdelku, ki se kaže muzikologu v obliki glasbe, muzikolog začenja prav pri glasbi in se skuša dokopati do izvornega skladateljevega glasbenega mišljenja. Vendar iz tega sledi le to, da morajo biti določena muzikologova znanja nujno identična s skladateljevimi. Ključno vprašanje pa je: ali lahko optiko tudi obrnemo - mora danes skladatelj imeti tudi nekatera muzikološka znanja?

To vprašanje je tesno povezano s slogovnim razsrediščenjem kompozicijskih praks, ta pa, kot smo že spoznali, v svoji posebni lokalni zaznamovanosti določa tudi snovanja slovenskih sodobnih skladateljev. Izguba orientirjev, središčnih navezovalnih točk prinaša dokončno uresničitev sintagme "anything goes", ki je ne gre razumeti več kot avantgardističnega rušenja tradicionalnega pojma umetniškega dela, temveč kot možnost vsakršnega sopostavljanja oz. koeksistence. Drug poleg drugega ali celo drug v drugem lahko sobivajo najrazličnejši kompozicijski slogi in tehnike, ne da bi bila mogoča njihova sistematična hierarhizacija. To pa hkrati pomeni tudi dokončen razpad skladateljskega metiera, saj ni več popolnoma jasno, katere so tiste veščine in znanja, ki bi jih moral nujno obvladovati prav vsak skladatelj. Skladatelj-umetnik je tako pred podobno težavo kot muzikolog-znanstvenik; skoraj nemogoče se namreč zdi, da bi obvladal ves zgodovinski in aktualni kompozicijski arzenal: od starih veščin (kontrapunkt, harmonija) do serialne tehnike, spektralne analize, postavljanja zapletenih struktur fraktalnih kompozicij, matematičnih algoritmov računalniških kompozicij, tehnologije komponiranja za elektroakustični medij itn. Zato se morajo skladatelji omejiti le na obvladovanje izseka take nepregledljive celote. Ker so osebnostne preference skladateljev različne, so različni tudi izbrani izseki - z njihovo razno-

\footnotetext{
6 Hans Heinrich Eggebrecht, Musikalisches Denken, v: Archiv für Musikwissenschaft 32 (1975), št. 3, str. 229.

7 Marija Bergamo, Muzikologija med znanostjo in umetnostjo, v: Muzikološki zbornik 34 (1998), str. 8.

8 Prav tam, str. 14.
} 
vrstnostjo se končujejo obdobja nadvlade posameznih slogov oz. šol in zmaguje postmodernistična razsrediščenost.

Vendar pa taka skladateljska izbira vendarle ne more biti povsem arbitrarna: že sam proces izbire namreč nujno vključuje refleksijo, torej misel o glasbi. Katerokoli pot že skladatelj izbere - radikalno inovativno (modernistično, morda celo avantgardistično) ali histori(cisti)čno -, vedno se izkaže kot ključno poznavanje tradicije. Skladatelj ne more prosto pisati v nekem histori(cisti)čnem slogu, če ga ne želi zgolj umetniško neambiciozmo kopirati, temveč dejavno soočati ali morda ironično potujevati, ne da bi tak zgodovinski slog tudi dobro poznal, hkrati pa je popolno distanciranje od vseh tradicij in iskanje novih poti nujno povezano s poznavanjem tradicije - nekaj je mogoče presegati le, če dobro poznamo izhodišče. Tako nadaljevanje kot tudi rušenje tradicije sta torej zvezana s poznavanjem tradicije in zakonitostmi njenega zgodovinskega spreminjaja: ta znanja pa poseduje muzikologija. Skladatelj, ki glasbo predvsem misli, mora danes tudi misliti o glasbi.

Za razjasnitev problemskega razmerja med sodobno slovensko kompozicijsko prakso in muzikologijo je tako ključno vprašanje, v kolikšni meri tudi slovenski skladatelji mislijo o glasbi, kako reflektirano je njihovo glasbeno mišljenje. Odgovor na tako vprašanje seveda ni enostaven, saj za njegovo razkrivanje nimamo pravih virov - glasbeno mišljenje se "kot proces ne da opisati, v posameznih potezah se ga ne da pojmovno opredeliti in utemeljiti, ne da se ga podvreči izračunu, ni ga mogoče konkretno prijeti." "Sam sem njegove ostanke skušal poiskati v izjavah skladateljev, dokumentiranih $\mathrm{v}$ koncertnih listih ob izvedbah njihovih del, pri čemer sem se seveda zavedal, da taki skladateljski zapisi niso vedno tudi veren odraz njihovega glasbenega mišljenja, da so v veliki meri odvisni od verbalnih sposobnosti, da včasih avtorji niti ne želijo razpreti vpogleda $v$ svojo skladateljsko delavnico in da bi jih bilo nujno obravnati vzporedno $\mathrm{z}$ analizo teh del. Vseeno pa zapisane misli vsaj v določeni meri zrcalijo način in logiko skladateljskega mišljenja in jih razumem kot bolj ali manj posrečeno verbalno transpozicijo glasbenega mišljenja, njihova kompleksnost in predvsem vsebina pa $\mathrm{v}$ omejenem obsegu razkrivata raven glasbene refleksije ali celo njeno odsotnost.

Pregledal sem koncertne liste orkestra Slovenske filharmonije in Simfonikov RTV Slovenija za oranžni, modri in zeleni abonma od sezone 1991/92 do 2001/02 - torej dobro desetletje po slovenski osamosvojitvi, pri čemer se zavedam, da ta politični datum verjetno niti nima pomembnejšega vpliva na snovanja slovenskih skladateljev, predstavlja pa "ugodno" periodizacijsko točko. Na ta način nisem zajel prav vseh slovenskih simfoničnih del, ki so bila krstno izvedena v tem času, temveč le tista, ki so bila izvedena na abonmajskih koncertih in so bila tako predstavljena najširši slovenski glasbeni javnosti, vključitev v sicer tradicionalno zasnovane abonmajske sheme pa naj bi potrjevala njihovo reprezentativnost in kakovost. V tem obdobju sta oba orkestra na svojih abonmajskih koncertih izvedla 59 simfoničnih del, ki so jih sloven-

9 H. H. Eggebrecht, nav. delo, str. 229. 
ski skladatelji napisali $\mathrm{v}$ zadnjem desetletju. ${ }^{10} \mathrm{Z}$ izjemo štirih skladb so vse ostale izvedbe skladatelji v koncertnem listu pospremili tudi $z$ lastnim komentarjem.

Prerez spremnih besed večinoma razkriva zadrege skladateljev pri ubesedovanju misli o svoji glasbi. Vzrokov za taka jezikovno in tudi muzikološko šibka besedila je verjetno več; nekateri skladatelji očitno niso najbolj vešči verbalnega izražanja (upravičeno lahko dvomimo, da nizek nivo jezikovnega izražanja takoj implicira že tudi nerazvito glasbeno mišljenje), drugi morda namenoma ne želijo razkriti podrobnosti svojega kompozicijskega procesa, tj. glasbenega mišljenja, pri nekaterih pa zakrnelost in redkobesednost verjetno vendarle izdajata tudi nereflektiranost kompozicijskega procesa. Pomenljivo je, da gre v treh od štirih primerov, ko v koncertnem listu ni skladateljeve lastne izjave, za istega skladatelja, kar razodeva njegovo stisko pri pisanju takih besedil ali splošne averzije do "verbaliziranja" glasbe. ${ }^{11}$ Ostale izjave pa lahko uredimo v šest skupin in jih nekako hierarhično uredimo od muzikološko neustreznih in vsebinsko praznih do strokovno tehtnih in vsebinsko povednih. Najmanjšo stopnjo reflektiranosti glasbenega mišljenja ali nizko željo po ubesedovanju problematike kompozicijskega procesa predstavljajo "prigodniški" zapisi (1) večinoma zahvale izvajalcem, solistom ali naročnikom, ${ }^{12}$ podobni pa so tudi razni "tavtološki" zapisi (2), v katerih skladatelji ponavljajo dejstva, ki so jasna tudi brez njihove razlage (npr. število in imena stavkov). ${ }^{13}$ Po številu prevladujejo navajanja

${ }^{10}$ Od tega jih je na svojih dveh abonmajih (modrem in oranžnem) Slovenska filharmonija izvedla 33, Simfoniki RTV Slovenija pa na zelenem abonmaju 26, kar nakazuje, da je radijski orkester v povprečju izvajal bistveno več novih del slovenskih skladateljev. Podoba po posameznih sezonah pa vseeno kaže precej klavrno podobo, saj je bilo največ novih slovenskih simfoničnih del (8) izvedenih v sezonah 1992/93 in 1998/99, najmanj (3) - za slovensko glasbeno kulturno politiko že kar škandalozno malo - v sezonah 1995/96, 1996/97 in 2000/01.

${ }^{11}$ Podoben primer predstavlja tudi naslednji zapis: „Komentar? Eh. Glasba prihaja iz popolnoma drugega sveta kot besede (vsaj zase lahko trdim tako). Po razmišljanju [sic!] kaj naj napišem, mi je prišlo v glavo, da ne bom žlobudral o zgradbi, orkestraciji ali karakterju in ne bom filozofiral o kakem smislu ali pa jo analiziral in skušal pojasnevati, ker je to čisto nepomembno. Človek odprtega srca jo bo sprejel in dojel... Naj povem le to, da ta simfonija prihaja nekje drugje, iz drugih sfer, zato je tudi $z$ realnimi besedami ne morem opisovati. To je svet, ki je hkrati bolj vesel in pravljičen ter istočasno bolj resničen in žalosten, $v$ njem pa so zajeti praspomin in pračustva. Še to - simfonija je bila napisana kot moje diplomsko delo, še pred odhodom v ZDA. Posvečam pa jo svojim staršem, še posebej očetu, ki me je popeljal v svet čudovite glasbe...." (Rok Golob, Koncertni list Simfonikov RTV Slovenija za 1. koncert zelenega abonmaja $v$ sezoni 1999/2000, 24. 9. 1999.)

${ }_{12}$ Prim.: Pavel Šivic, Koncertni list orkestra Slovenske filharmonije za 1. koncert oranžnega abonmaja v sezoni 1994/95, 29. 9.1994 ("Svoje Freske za simfonični orkester sem posvetil Ivu Petriću, umetniškemu vodji Slovenske filharmonije, za opazne zasluge, ki jih ima za slovensko glasbeno kulturo. Pod njegovim umetniškim vodstvom je filharmonični orkester dosegel zavidljivo poustvarjalno raven, $\mathrm{v}$ Ljubljano je pripeljal imenitne dirigente in $\mathrm{z}$ dopadljivo repertoarno politiko že več let do vrha polni abonentske koncerte.// Svoje tri stavke za simfonični orkester sem naslovil Freske, ker v njih nizam glasbene epizode takó, kot slikar nanaša svoje barvne ploskve brez ostrih kontur na belo podlago. Freske so nastale letos spomladi.. in Jani Golob, Koncertni list Simfonikov RTV Slovenija za 6. koncert zelenega abonmaja v sezoni 1994/95, 7. 4. 1995 ("Variacije za violino, klavir in orkester sem napisal po naročilu Glasbenega programa Radia Slovenije za gostujoča umetnika - violinista Sergeja Krilova in pianistko Stefanio Mormone, ki tudi sicer redno nastopata kot uspešen koncertantski duo.// Komponiranje za ta sijajen duo je bilo zame še poseben izziv in upam, da bo tak izziv tudi za izvajalca.").

${ }^{13}$ Prim.: Marjan Gabrijelčič, Koncertni list Simfonikov RTV Slovenija za 5. koncert zelenega abonmaja v sezoni 1992/93, 5. 3. 1993 ( Zvočna znamenja za violončelo in orkester so bila nared na začetku leta 1993. Naročilo zanje sem dobil od vodstva RTV Slovenije in zato se zahvaljujem.// Skladba ima tri stavke: Allegro molto attaca, Adagio, Allegro, z vmesnimi spremembami tempov, seveda.// Solistu je namenjena obsežna vloga, zahtevna po izvajalsko tehnični, še posebej pa po glasbeno izrazni plati. Snov in gradnja skladbe dajeta solistu-violončelistu veliko možnosti, prav tako pa tudi simfoničnim solistom.// Glede sporočilnosti pa - odvisna je od dojemljivosti in občutljivosti vsakega posameznika in pojasnila zato niso potrebna.") in Samo Vremšak, Koncertni list orkestra Slovenske filharmonije za 1. koncert oranžnega abonmaja v sezoni 1997/98, 2. 10. 1997 ("Suita za orkester je bila končana v lanskem letu. Obsega sedem stavkov 
okoliščin, ki so pripeljala do ideje za kompozicijo (3) - taki zapisi razkrivajo sprožitev kompozicijskega procesa, ne pa tudi dejavnosti same in s tem pravega glasbenega mišljenja. ${ }^{14}$ Razgaljanje navdiha je razvidno tudi iz besedil, v katerih skladatelji predstavljajo poetični program svoje skladbe (4). Taki spremljajoči teksti se zdijo še posebej smiselni, kadar skladatelji z njim skušajo razložiti vokalno-instrumentalno delo, ${ }^{15}$ $\mathrm{v}$ katerem ima pomembno vlogo za razumevanje dela tudi izbrano besedilo, bolj nedorečeni in izmuzljivi pa se zdijo kot opisi instrumentalnih del, saj je iz njih mogoče razpoznati le prevladujočo atmosfero dela oz. razpoloženje skladatelja $\mathrm{v}$ trenutku, ko je pisal skladbo. ${ }^{16}$ Redki so poizkusi analitičnih prerezov skladb (5), pa še ti se

pretežno plesnega značaja, kot je razvidno iz naslovov stavkov. Želel sem ustvariti delo, večji del vedrega karakterja, dovolj razgibano tudi v ritmičnem pogledu. Intrada ima svečan izraz, kot tej obliki tudi pritiče. Saltarello je precej živahen. Pavana ima nekoliko resnobnejši pridih. Galliarda je zopet razgibana. Tango je umirjen in rahlo otožen. Marche se ne oddaljuje od karakterja večine te glasbene oblike. Kólo (rondeau) se začenja v zelo počasnem tempu, se nato stopnjuje, dokler se v razbrzdanem tempu ne zaključi. Ima nekaj potez južnjaškega kola.").

${ }^{14}$ Prim.: Pavel Šivic, Koncertni list orkestra Slovenske filharmonije za 2. koncert modrega abonmaja v sezoni 1992/93, 5. 11. 1992 ( $Z$ velikim zanimanjem sem po vojni sledil vsem dosegliivim izvedbam kantate Carmina burana nemškega skladatelja Carla Orffa tako pri nas kot drugod. Ko je konec sedemdesetih let v tisku izšlo originalno latinsko besedilo teh mestoma kar kosmatih srednjeveških pesmi skupaj z izvrstnim prevodom Primoža Simonitija, so me nekatere tako navdušile, da sem jih uglasbil za tenor in orkester. Pri tem nisem upošteval, da so nekatera besedila teh študentskih pesmi iz samostana Benediktbeuern na Bavarskem ohranjena tudi s podloženo melodijo $\mathrm{v}$ prepričanju, da oprijemljivost samega besedila nudi dovolj možnosti za povezavo s koncertantno glasbo."), Ivo Petrić, Koncertni list orkestra Slovenske filharmonije za 2. koncert modrega abonmaja v sezoni 1993/94, 11. 11. 1993 ("Leta 1991 smo se Slovenci poleg vsesplošnega proslavljanja Mozartove obletnice spominjali tudi 400-letnice smrti enega največjih renesančnih skladateljev, ki je bil našega rodu. Moram priznati, da me ta domača evforija sprva ni prepričala, ko pa sem na televiziji videl enkratno televizijsko baletno postavitev Milka Šparembleka, ki je sijajno izkoristil Gallusovo glasbo za koreografsko vizijo svetovne kvalitete, se mi je utrnila misel, ki me ni zapustila vse dotlej, dokler se nisem odločil tudi sam postaviti delček spomenika temu našemu velikemu predhodniku. Poglobil sem se $\mathrm{v}$ tri njegove znane in imenitne stvaritve (Quam pulchra es, amica mea... Ecce quomodo moritur iustus... Musica noster amor...) in jih vzel za srž mojega meditiranja in metamorfoz ob njem, z njim in... toliko let po njem. [...] Zavedam se, da je takšno spajanje pretekle zgodovine in sedanjosti zelo tvegana zadeva in da se le redkokdaj posreči, potešil pa sem svoj dolg do tega velikega mojstra in se skromno pridružil praznovanju visokega jubileja, ki ga je njegova glasba vzdržala vse do današnjih dni.") in Alojz Ajdič, Koncertni list orkestra Slovenske filharmonije za 8. koncert oranžnega abonmaja v sezoni 1998/99, 6. 5. 1999 ("Ko sem leta 1994 vsakodnevno poslušal poročila o številu mrtvih v Sarajevu in drugih krajih Bosne in Hercegovine, me je nekega jutra pretresla novica, ko je napovedovalka prebrala, da so tega dne ostrostrelci ubili dečka $z$ violino. Ta novica me je tako pretresla, da sem tisti trenutek ves šokiran in zgrožen sam sebe vprašal: Pa kaj vam je naredil ta ubogi deček! Podoživljal sem njegove zadnje trenutke življenja in ker sem v tistem času pisal danes izvajani koncert za violino, sem sklenil, da to delo posvetim vsem glasbenikom v Bosni in Hercegovini, ki so padli v tej nesmiselni vojni.*).

${ }^{15}$ Prim.: Lojze Lebič, Koncertni list Simfonikov RTV Slovenija za 8. koncert zelenega abonmaja v sezoni 1998/99, 17. 5. 1999 ([...] Skladba je štiridelna, a poteka v enem. Glasbeno vsebinska razpoloženja je mogoče razbrati iz naslovov pesmi [sic!] kot si sledijo. Prvi ŠE VEČ VEMO PA NE POVEMO meri na nedoumliive skrivnosti človekove duše; drugi DOLGO TIHO je na videz pripoved o naravi in preprostem bivanju. Izžareva nevarno začaranost; tretji, dramatični del skladbe, ima za pesemsko osnovo dve znani baladi: GODEC PRED PEKLOM in MRTVAŠKA KOST. V sodobni pesniški in glasbeni preobrazbi sta polni ironije in grotesknih poudarkov, vendar je v tej apokrifni preoblikovanosti čutiti tragičnost našega bivanja in umiranja ter neizbežnost kazni za človekovo objestnost. Četrti, sklepni del skladbe, glasba slovesa, prihaja iz prvinskega animizma in se končuje z besedami: 'prosim, vzemi me nazaj dež, oblak... ti ptica in voda in kamen... vzemi me nazaj še pred mojo smrtjo...' [...]).

${ }^{16}$ Prim.: Pavel Mihelčič, Koncertni list orkestra Slovenske filharmonije za 1. koncert oranžnega abonmaja $v$ sezoni 1995/96, 5. 10. 1995 ("V tišini ima zvok čisto drugačno vrednost. Poslušamo ga in ga uvrščamo. V mozaiku drobnih zvočnih dogodkov iščemo harmonijo in melodije, odkrijemo ritme in najdemo barve. Glasba se rojeva v tišini, tudi odide v tišino. In ko iščemo tišja zvočna razpoloženja, se dotikamo narave. Tudi v naravi so zvoki urejeni. Prav tam, na primer v gozdu, pa se zgodba o zvoku v resnici začne. Vrnitev v tišino je moj pogled na naravo. To je zgodba o zvoku, ki išče svoj začetek, svoj prazvok. [...] Melodija je v dotiku z naravo. Pesem gozdne ptice je komaj slišna poanta: vrnitev $\mathrm{v}$ tišino.") in Rok Golob, Koncertni list orkestra Slovenske filharmonije za 8. koncert oranžnega abonmaja $v$ sezoni 2001/02, 18. 4. 2002 ("I. Otroci gozda živijo sredi divjine in nihče ne ve, da obstajajo. Ker so globoko v pragozdu in daleč od civilizacije, živijo posebno življenje. Le izjemoma kakega popotnika zanese tako daleč v gozd in takrat se pravočasno skrijejo, saj imajo neverjetne sposobnosti zaznavanja. Po nekem čudnem naključju 
večinoma razvodenijo $\mathrm{v}$ natančno popisovanje posameznih formalnih delov ali orkestracijskih prijemov, manj pa izpostavljajo osrednjo problematiko skladbe. ${ }^{17}$ Nekatera spremna besedila pa vendarle razkrivajo tudi bolj reflektirano glasbeno mišljenje, saj skladatelji v njih razgrinjajo osnovna kompozicijsko-tehnična vodila svoje skladbe, ponujajo bolj problemsko zastavljeno analizo dela, skušajo opravičiti nekatere formalne dileme ali pa natančno razlagajo vlogo nekega zunajglasbenega dejavnika pri nastanku glasbene strukture (6). Lojze Lebič se tako ob svoji Simfoniji z orglami sprašuje o vlogi in pomenu simfonične forme v sodobnem trenutku, ${ }^{18}$ ob krstni izvedbi Glasbe za orkester - Cantico I pa izpostavlja kompleksno razmerje med literarnim nagibom in avtonomnostjo glasbe ter razkriva formalno zasnovo dela, ki sloni na sumacijskem razmerju. ${ }^{19}$ Neville Hall, ki se tudi edini sprašuje, kaj naj v svojem ko-

sem jih našel... [...]// II. Eternal je večen, neskončen in zame zelo oseben. Posvečam ga svojemu pokojnemu dedku in vasici Žetale, v kateri je živel. Predstavljajo mi čudovite spomine, srčnost, preprostost in povezanost $\mathrm{z}$ naravo. Hvala nekje nekomu za melodije... Eternal.// III. La vira agnias je bitka svetlih in temnih sil. Bitka iz vzporednega sveta. Medplanetarna. Je tu, pa ni. Včasih se nam pokaže v sanjah, včasih v prebliskih. Domišljija ne obstaja. Je le del mozaika brezčasnosti, brezprostornosti, informacija iz vesolja. Vse se je že zgodilo, vse se dogaja in vse se bo zgodilo. Energija je ena. La viora agnias je vse.").

17 Prim.: Peter Šavli, Koncertni list orkestra Slovenske filharmonije za 9. koncert oranžnega abonmaja v sezoni 1991/92, 4. 6. 1992 ([...] Orkestralni uvod je grajen v razčlenjeni in svojstveni orkestraciji, altsaksofon pa nastopi s svežo obdelavo istega materiala. Melodične bravure solista pregibajo zvok skozi sorodne tempe. Dvojno zvočnost orkestra in solista v drugem stavku obarva baritonski zvok saksofona. V začetku drugega stavka nastopi osnovna kvaliteta zvoka - barva, ki jo nato instrumenti zlagoma melodično oblikujejo. Smiselnost melodičnih dogodkov se preseka z dramatičnim orkestralnim vložkom, ki se umiri v ponovno altovsko barvo saksofona. Pettaktni valovi sozvočij in melodij zastanejo pred kratko solistično kadenco. Tretji stavek prinaša elemente klasičnega koncerta, je bolj sproščen in razumljivejši. Prevzema tudi elemente prvega stavka, konec pa je umirjen. [...]) in Vladimir Hrovat, Koncertni list Simfonikov RTV Slovenija za 5. koncert zelenega abonmaja v sezoni 1994/95, 3. 3. 1995 ("Že v uvodu oz. predigri se v aleatoričnem delu pojavljajo motivi obeh osnovnih tem. Nekoliko spreminjajoči se motiv druge teme poteka ves čas v basovski liniji, tako nekako kot v passacagliji. V trobentah, pozneje še v rogovih, 1. trombonu in baritonu (baritonski rog) pa se oglašajo fragmenti motiva prve teme. Sklepni del nas pripelje do standardne ekspozicije sonatnega stavka. Le-ta vsebuje bolj razgibano prvo in preprostejšo, predvsem v prvem nastopu in potem reprizi spevnejšo, sicer sekvenčno drugo temo ter zaključek, nakar se ponovi v nekoliko spremenjeni obliki. Potem pa sledi - recimo temu - presenečenje. Izpeljavo istočasno uporabim kot nekakšen počasni 'drugi stavek', saj ima tudi predpisan enkrat počasnejši tempo. Pojavi se celo nova snov, lahko ji rečemo kar tretja tema, iz dela katere sredi 'počasnega stavka' izpeljem krajšo štiriglasno fugo; tej se na koncu pridruži še intervalno obrnjen peti glas v basovski liniji. Med 'dogodke' počasnega dela - te, sicer vendarle enostavčne skladbe - sodi še nekajkratna navzočnost različno obdelanih fragmentov prve teme, nekoliko več druge in vnovično pojavljanje motiva druge teme $\mathrm{v}$ basovski liniji na način passacaglie, podobno kot $\mathrm{v}$ predigri, poteka pa sočasno 's' oz. 'pod' fugo. Sklep počasnega dela nas pripelje v reprizo spet nekoliko spremenjene eskpozicije, $z$ vrhuncem na pospešenem (stretto) koncu, v katerem poleg motiva prejšnjih zaključkov eskpozicije slišimo hkrati še motiva prve in druge teme.").

${ }^{18}$ Prim.: Lojze Lebič, Koncertni list Simfonikov RTV Slovenija za 1. koncert zelenega abonmaja v sezoni 1993/94, 8. 10. 1993 ("Zamisel za tovrstno delo sega že v čas pred petnajstimi leti, ko sem napisal orgelsko skladbo 'Okus po času, ki beži...' V letošnjem delu kljub naslovu ne obnavljam preteklega simfonizma, na katerega je vezanih preveč določnih glasbeno vsebinskih opredelitev iz začetka romantičnega 19. stoletja, pa tudi klasičnega simfoničnega (sonatnega) oblikovnega shematizma danes ni smiselno oživljati. Toda vse to vendarle živi v nas kot skupni spomin, ki napoveduje zvočno razsežnejši energetski prostor, v katerem bodo imele izpeljave prednost pred kontrasti, povezave pred prelomi, velik zvok pred komornostjo in širša celota pred posameznostmi.// Melodično vezivo 'Simfonije z orglami' je izpostavljeno takoj na začetku v podobi prepoznavnih (redundantnih) tonskih likov in figur oblikovanih po koralu 'Rorate caeli desuper, et nubes pluant justum:...' Ti se iz začetnega oktavnega vzgiba simetrično razraščajo, hierarhično večajo in - danes bi modno rekli - fraktalno širijo v tonski prostor. In z njimi tudi zvočna domišljija - kot da nas vodi zdaj po poznani zdaj po tuji pokrajini, ki nas kdaj razveseljuje drugič razočara, vselej pa preseneča.// Simfonija z orglami je nastala po naročilu glasbenega uredništva RTV Slovenija. Nocoj bo njena krstna izvedba.").

${ }^{19}$ Prim.: Lojze Lebič, Koncertni list orkestra Slovenske filharmonije za 4. koncert modrega abonmaja $v$ sezoni 1997/98, 18. 12. 1997 ("Glasba za orkester - CANTICO I je prvi del diptiha. Zamisel zanj se je porodila ob dveh vznemirljivih besedilih, enem iz 13. in drugim iz našega stoletja. Obe začenjata $z$ besedo hvalnica (Cantico... Hymne...). Literarni nagib se je pozneje umaknil avtonomnosti glasbene govorice, stopil v ozadje, skladatelju pa je ostal kot ustvarjalni 
mentarju zapiše, da bo v pomoč poslušalcu, razlaga fraktalno strukturo svojega dela Silence Rained Down Quenching Time's Fire in oblikovne implikacije take kompozicijske zasnove. ${ }^{20}$ Božidar Kos opisuje ob delu Aurora Australis naravni pojav (polarni sij) in princip njegovega "prevoda" $\mathrm{v}$ glasbeni stavek, ${ }^{21}$ po vsebini pa je temu podobno tudi besedilo Larise Vrhunc ob izvedbi skladbe Hologram. ${ }^{22}$

simbol. Naslov torej ni nosilec zgodbe, zgodba je glasba sama.// Ta začne s 'pra-udarcem' polnega orkestra, v katerem so sežeti vsi poznejši harmonski liki. Takoj za tem tolkalci izpostavijo tudi vse ritmične vzorce, ki se pozneje proti koncu razrastejo v obsežno kadenco. Celota je iz treh med seboj povezanih delov. Prvi, najbolj kontrasten, je iz štirih enot, drugi - nekak nocturno - iz treh. Preko starinske negibnosti čembala preide skladba v enovito usmerjeno stopnjevanje tretjega dela.// Nakazano sumacijsko razmerje 1, 3, 4, 7... opredeljuje formalno zgradbo celotnega diptiha, po svoji simboliki pa tudi vse druge skladateljeve odločitve. [...]").

${ }^{20}$ Prim.: Neville Hall, Koncertni list orkestra Slovenske filharmonije za 3. koncert modrega abonmaja $v$ sezoni 1999/ 2000, 2. 12.1999 ("Kaj lahko reče skladatelj ali skladateljica o svojem delu, da bi bilo zanimivo ali celo koristno za poslušalce? Izkušnja, ko prvikrat poslušamo sodobno glasbeno delo, je lahko izzivalna, brez dvoma pa tudi zahtevna. Ker poznamo prav toliko pristopov k skladanju, kolikor je skladateljev, mora biti poslušalstvo pripravljeno opustiti običajni način poslušanja in poiskati nove. Upam, da bo kratki komentar, ki sledi, lahko služil kot izhodiščna točka za krmarjenje po zvočnem svetu tišine, ki dežuje...// Vsi 'dogodki', ki sestavljajo pričujoče delo, so nekako izpeljani iz enega središčnega dogodka, ki ga slišimo proti koncu dela. Začetek tega dogodka označuje močan hkratni izbruh harfe, klavirja in uglašenega tolkala, katerega resonanco prevzamejo in nežno vzdržujejo godala. Bistvo te zvočne konfiguracije se skozi delo pogosto pojavlja, hkrati pa se spreminja in postopoma razgradi. Vsi ostali dogodki so bili 'zloženi' po strukturni pomembnosti, tako da so se od središčnega dogodka odmikali v koncentričnih krogih in ne po vrstnem redu njihovega pojavljanja $\mathrm{v}$ delu. Tako je torej ideja časovne kontinuitete ali glasbe kot kvazilingvističnega diskurza opuščena v podporo skoraj prostorske/arhitekturne/kiparske kontinuitete z 'genetsko' povezanimi dogodki, razpršenimi skozi skladbo.// Toda ta 'razpršenost' je daleč od naključne. Sledi določenim principom, tako da se poslušalec zave slojevitosti in kopičenja gradiva, saj se dogodki nalagajo in postopoma pridobivajo na teži. Pravzaprav gre $\mathrm{v}$ tem primeru za obrnjen skladateljski proces. Med skladbo naletimo na zaporedno razpršitev gradiva, saj se dogodki iz osnovne ideje, vse bolj in bolj razvijajo ter oblikujejo drevesu podobno strukturo...// Čeprav je v glasbi več dolgih tišin, to niso tiste, na katere se nanaša naslov. So rezultat snovnega drobljenja in razkosavanja med procesom skladanja. Včasih se je zdelo mikavno odstraniti ali omejiti te tišine, toda naposled je bilo, $v$ tem pogledu, skladbi dovoljeno določiti samo sebe. Če imamo v mislih, da cilj ni bil doseči časovno kontinuiteto, postanejo tišine manj problematične, tako da delujejo bolj kot 'prazen prostor' kot pa časovni razdelki.// Reči nekaj o 'tišini' in 'času' iz naslova, je precej težje. Morda bi ju lahko nadomestili z drugimi dihotomijami kot 'duhovno/snovno', 'prostorsko/časovno', 'nevidno/ vidno', 'neizgovorljivo/izgovorljivo', 'poetično/prozaično'...").

${ }^{21}$ Prim.: Božidar Kos, Koncertni list orkestra Slovenske filharmonije za 4. koncert oranžnega abonmaja v sezoni 2000/ 01, 1. 2. 2001 ("Aurora Australis je polarni sij, ki je viden ponoči na južnem nebu kot bleščeč trepetajoč žar. Pojavlja se v neskončnih različicah, a najbolj pogosto kot valovi in nagubane plasti barvaste svetlobe. Svetlobne zaplate in stolpci $\mathrm{v}$ raznih barvnih odtenkih se naglo premikajo sem ter tja, kot da plešejo visoko $\mathrm{v}$ atmosferi, pod njimi pa je temno nebo.// Aurora pomeni tudi svitanje, jutranja zarja ali zora. V prenesem smislu bi lahko rekli, da pomeni tudi začetek tistega, kar se bo šele zgodilo, nečesa, kar je še nepoznano in skrivnostno. Skladba Aurora Australis ni programsko delo, vendar pa po zgradbi spominja na ta atmosferski pojav. Oblika skladbe poteka v valovih in orkestrske barve se nenehno spreminjajo. Glasbeno gradivo, ki ga igrajo flavte, oboe in klarineti, pogosto vzbuja vtis migljajočega, bleščečega zvočnega tkiva, medtem ko tolkala često igrajo domala plesne ritme zelo potiho, kot da so ti izvajani nekje $\mathrm{v}$ daljavi. Fagot, kontrafagot in tuba pa igrajo, posebno v prvem delu skladbe, globoke in počasne melodije, ki predstavljajo temno stran zvočnega spektra.// Skladba je zasnovana na harmoničnem in zunajharmoničnem spektru. Številne tonske višine se zato razlikujejo od tradicionalnih tonskih višin; včasih za približno šestino, drugič pa za četrtino. [...]").

${ }^{22}$ Prim.: Larisa Vrhunc, Koncertni list Simfonikov RTV Slovenija za 1. koncert zelenega abonmaja v sezoni 2001/02, 5. 10. 2001 ("Hologram je tridimenzionalna slika, ki jo ustvarja interferenca med dvema snopoma svetlobe. Edem od snopov se odbije od nekega predmeta, drugi pa rabi kot nosilec slike. Pričujoča skladba je kot igra svetlobe, ki potuje od izvira k prizmam, ki jo cepijo, žarki se srečujejo, dokler na koncu ne nastane hologram. Ta nato počasi izgine. To je seveda samo ena od možnih zgodb. Hologram ima namreč lahko tako kot drugi modeli iz naravoslovja tudi simbolni pomen.// Obstaja teorija v psihologiji, ki pravi, da možgani zapisujejo dogodke v obliki holograma: vsak zapis je sestavljen iz srečanja naših preteklih izkušenj z doživetjem dogodka. Zato lahko isti dogodek vsakdo občuti drugače./ / Tudi pri dojemanju glasbe je to zelo očitno: ob poslušanju skladbe so odzivi poslušalcev zelo različni glede na njihov okus, trenutno počutje, poznavanje glasbenega jezika in podobno. Ta pojav sem uporabila za igro s poslušalčevimi pričakovanji: ob poslušanju si predstavljamo, da se bo glasba nadaljevala na določen način, zgodi pa se nekaj drugega: šele ob zadnjih tonih vsi prej slišani drobci dobijo svoje pravo mesto."). 
Pomenljivo je, da našteti skladatelji, ki očitno posvečajo več pozornosti zapisanim mislim ob izvedbah skladb in s tem posledično namenjajo tudi več časa mislim o glasbi, ki jo pišejo, pripadajo podobni slogovni orientaciji - glasba vseh raste iz modernistične usmeritve in jo tako določata želja po inovativnosti, močni lastni izraznosti ter zaupanje adornovski "tendenci materiala". Gotovo ni nepomembno, da sta bila oz. sta L. Lebič in L. Vrhunc $v$ aktivnem kontaktu $\mathrm{z}$ muzikologijo - oba sta poučevala oz. poučujeta na ljubljanskem Oddelku za muzikologijo Filozofske fakultete, medtem ko je delo B. Kosa in N. Halla zaznamovala "tujina": v prvem primeru gre namreč za Slovenca, ki deluje v tujini, in v drugem za "tujca", ki živi in komponira v Sloveniji. Modernistična iskanja so torej očitno nujno povezana s poudarjeno mislijo o glasbi in morajo živeti v ozki zvezi z muzikološkim razgrajevanjem sodobne ustvarjalnosti, kratek prerez zapisanih misli v koncertnih listih pa izdaja, da so mnogo manj reflektirana snovanja tistih skladateljev, ki svojo ustvarjalnost pogosto skušajo postaviti v zvezo $\mathrm{z}$ modnim postmodernizmom. ${ }^{23} \mathrm{~Pa}$ vendar se $\mathrm{zdi}$, da je tudi za postmodernistična sopostavljanja, palimpseste, citate in pastiše nujna skladateljska refleksija, ki sploh šele omogoča tvorna soočanja in konfliktne potujitve. Zato se zastavlja vprašanje, ali lahko dela skladateljev, ki se odločajo za "prebavljive smeri ${ }^{24}$ in zato oporo iščejo v nekontroliranem navezovanju na pretekle, že znane modele, sploh razumemo kot postmodernistična? Ali ne gre bolj za željo po podeljevanju koncesij poslušalstvu, ugajanju in "tržnemu" uspehu - vse to je mogoče povezati $z$ današnjo informacijsko prepleteno in globalno potrošniško postmoderno družbo?

Pregled zapisov v koncertnih listih posredno razkriva slabo povezanost med slovensko kompozicijsko prakso in muzikologijo: zavest o pomembnosti misli o glasbi je pri mnogih slovenskih skladateljih slabo razvita. Krivde za tako samozadostnost pa ne gre prelagati samo na eno stran, saj sta obe $\mathrm{v}$ resnici soodvisni. Tudi slovenska muzikologija mora ponuditi znanja in informacije, ki bodo slovenskim skladateljem $\mathrm{v}$ pomoč pri njihovem glasbenem mišljenju. To pa lahko dosežemo le z odpiranjem navzven, zato se bo moj sklep glasil nekoliko paradoksalno. Slovenski glasbeni kulturi in kompozicijski praksi lahko slovenska muzikologija najbolje služi s preučevanjem svetovnih glasbenih tokov in dogajanj, torej $z$ informiranjem, povezovanjem in aktivnim primerjanjem naše glasbene kulture s svetovno. $Z$ odpiranjem prek meja pa muzikologija ne služi le kot informacijski "servis" skladateljem, temveč prihaja v dotiki z najnovejšimi muzikološkimi metodami, ki jih lahko aplicira tudi na svoje gradivo: slovensko glasbo. Tak je tudi moj odgovor na temo našega simpozija muzikologija kot nacionalna veda $v$ evropskih in globalnih integracijskih procesih - staro paradigmo bi samo nekoliko zaobrnil: danes mora biti muzikologija najprej svetovna, da bi bila lahko potem tudi nacionalna.

${ }^{23}$ Prim.: Marko Mihevc, Koncertni list orkestra Slovenske filharmonije za 6. koncert modrega abonmaja v sezoni 2000/01, 15. 3. 2001 ("Privlači me individualno iskanje vedno novih poti, tistih, ki podčrtavajo razpoznavnost moje glasbe. Iščem nove elemente, nikoli pa ne dodam toliko novega, da bi prestopil rubikon svojega lastnega sistema. Nekateri vplivi se lahko v mojih kompozicijah postmodernistično preoblikujejo in združujejo v povsem nov izraz. Menim, da nastopa novo obdobje v glasbi, ko se bo v pogledu kompozicijske tehnike atonalnost pomešala s tonalnostjo, predvsem v obliki več plasti, ki sočasno lebdijo druga nad drugo. Uho poslušalca pa lahko iz te večplastnosti izlušči, kar mu je najbližje... Nihče ni popolnoma neobremenjen individualist; tudi jaz ne, vendar pa si upam trditi, da me ljudje prepoznajo in ločijo moj način izražanja od glasbe drugih... [...]»).

${ }^{24}$ Pogovor s skladateljem Markom Mihevcem. Eva Senčar, V resni glasbi ni dobrih naivcev, v: Delo 41, 16. 1. 1999, str. 40. 